\title{
Selective visualization of monoamine uptake and synthesis system in sea urchin larvae Paracentrotus lividus (Lamarck, 1816)
}

\author{
A.L. Obukhova, M.Yu. Khabarova, E.E.Voronezhskaya \\ Institute of Developmental Biology, RAS, Vavilov st. 26, 119991, Moscow, Russia. \\ E-mails: allobukhova@gmail.com,m.khabarova@yandex.ru,lenavor@gmail.com
}

\begin{abstract}
We tested a method for the early visualization of neuronal elements in the larvae of sea urchin Paracentrotus lividus. Application of external serotonin (5-HT) and dopamine (DA) led to an increase in the mediator content within a specific set of neurons capable to 5-HT and DA uptake. Application of biochemical precursors 5-HTP and LDOPA resulted in non-selective mediator increase within the most neurons of the larval body. In addition, primary mesenchyme cells which participate in the formation of spicules appeared to synthesize 5-HT from the precursor. Applied method of 5-HT and DA enhancement allows to visualize larval neurons long before they become labeled by routine immunochemical and hystochemical methods.

How to cite this article: Obukhova A.L., Khabarova M.Yu., Voronezhskaya E.E. 2017. Selective visualization of monoamine uptake and synthesis system in sea urchin larvae Paracentrotus lividus (Lamarck, 1816) // Invert. Zool. Vol.14. No.2. P.162-166. doi: 10.15298/invertzool.14.2.10
\end{abstract}

KEY WORDS: serotonin, dopamine, sea urchin larvae, neuronal elements.

\section{Селективная визуализация системы захвата и синтеза моноаминов у личинок морского ежа Paracentrotus lividus (Lamarck, 1816)}

\section{А.Л. Обухова, М.Ю. Хабарова, Е.Е. Воронежская}

Институт биологии развития РАН, Вавилова 26, Москва, 119991, Россия.

E-mails: allobukhova@gmail.com,m.khabarova@yandex.ru,lenavor@gmail.com

РЕЗЮМЕ: Мы протестировали метод ранней визуализации нейрональных элементов у личинок морского ежа Paracentrotus lividus. Аппликация серотонина (5-НT) и дофамина (DA) приводила к увеличению содержания медиатора в определенных нейронах, способных захватывать 5-НT и DA. Аппликация биохимических предшественников - 5-HTP и L-DOPA, приводила к неселективному увеличению уровня медиатора в большинстве клеток в теле личинки. Кроме этого, оказалось, что клетки первичной мезенхимы, участвующие в образовании спикул, способны синтезировать 5-НТ из предшественника. Использованный метод повышения уровня 5-НТ и ДА позволяет визуализировать личиночные нейроны задолго до того, как они начинают выявляться при помощи стандартных иммунохимических и гистохимических методов. 
Selective visualization of monoamine uptake and synthesis system in sea urchin larvae 163

Как цитировать эту статью: Obukhova A.L., Khabarova M.Yu., Voronezhskaya E.E. 2017. Selective visualization of monoamine uptake and synthesis system in sea urchin larvae Paracentrotus lividus (Lamarck, 1816) // Invert. Zool. Vol.14. No.2. P.162-166. doi: 10.15298/invertzool.14.2.10

КЛЮЧЕВЫЕ СЛОВА: серотонин, дофамин, личинка морского ежа, нейрональные элементы.

\section{Introduction}

Sea urchin larvae are widely used for indepth investigations of neuronal monoaminemediated (including both serotonin and dopamine) control of cilia-based locomotion. On the other hand, the very first neural elements containing 5-HT and DA appear clearly at the stage of late gastrula (first 5HT-positive cell) and, later, are reliably detected at the pluteus stage (Bisgrove, Burke, 1987). At the same time, sea urchin larvae are capable of coordinated swimming immediately after hatching. This paradoxical situation allows to propose that first monoaminergic cells differentiate at the very early stages, much earlier than currently expected, but were never reliably visualized because of the low neuromediator content.

In this study, we tested two independent methods that enable visualizations of such cells at much earlier stages than previously demonstrated. This is supported by the fact that some larval neurons (for example in gastropod embryos) synthesize and perform uptake of monoamines before the actual efflux of neuromediators (Voronezhskaya et al., 2004). This is happening because the cells express corresponding monoamine-synthesis enzymes and transporters already at the differentiation stage and are ready to perform at the onset of a functional readiness. Despite the presence of neuromediators in small quantities at the early stage, visualizations of such neuromediator amounts are rather hard if not impossible with the current methodology based on immunochemical and histochemical approaches. To boost the intracellular neuromediatory content at the very early stages for visualizing differentiating cells, we developed a novel pharmacological strategy.
This strategy turned out to be efficient and helpful when it comes to visualizing early differentiating neurons. Additionally, it enabled discrimination of the capacity of these cells to produce versus to uptake the neuromediators.

Previously, a similar logic has been utilized to study physiology of central ganglia neurons of mollusk (Sakharov, 1991), while in our case the improved strategy was successfully tested for morphological visualization of early neurons in developing embryos and larvae of sea urchin Paracentrotus lividus.

\section{Materials and methods}

Adult $P$. lividus were collected near Paphos, Cyprus. Spawning was induced by intracoelomic injection of $0.5 \mathrm{M} \mathrm{KCl}$ and eggs were collected and fertilized in filtered seawater (FSW). Embryos and larvae were cultured at $18-20^{\circ} \mathrm{C}$. In the study, we used larvae on the stage of gastrula and early pluteus. To identify cells capable of serotonin (5-HT) and dopamine (DA) synthesis and uptake, larvae were incubated in $25 \mu \mathrm{M}$ solutions of monoamines (5-HT and DA) and their biochemical precursors (5-hydroxytryptophan, 5-HTP and L-3,4-dihydroxyphenylalanine, L-DOPA) for 1 hour before fixation.

Larvae were fixed in 4\% paraformaldehyde in FSW at the appropriate developmental stages. Prior to antibody treatment, embryos were washed with $0.01 \mathrm{M}$ phosphate- buffered saline with $0.5 \%$ Triton X-100 (PBS-TX) three times, and then incubated for $12-24 \mathrm{~h}$ at $4{ }^{\circ} \mathrm{C}$ with rabbit antibodies against 5-HT (Sigma Aldrich Japan; 1:1000) and mouse antibodies against acetylated $\alpha$-tubulin (aTub), (Sigma Aldrich Japan; 1:2000), diluted in 0.5\% PBS-TX. After 
staining with the primary antibodies, the samples were washed with $0.1 \%$ PBS-TX three times, and treated with Alexa Fluor 488-tagged anti-rabbit IgG and 633-tagged anti-mouse IgG antibodies (Invitrogen, Paisley, UK), diluted $1: 800$ in $0.1 \%$ PBS-TX for $6-12 \mathrm{~h}$ at $4^{\circ} \mathrm{C}$. Samples were then washed with $0.1 \%$ PBS three times and immersed in $70 \%$ glicerol. The samples were examined under a confocal laser scanning microscope Leica TCS SP5 (Leica, Germany) with appropriate wavelength filter configuration setting.

The primary fixative used for the histochemical detection of catecholamines (DA, particularly) consisted of a mixture of $4 \%$ formaldehyde and $0.5 \%$ glutaraldehyde in $0.01 \mathrm{M}$ phosphate buffer, $\mathrm{pH} 7.4$ with $30 \%$ sucrose (referred to as the FaGlu mixture). Samples stored in FaGlu mixture at $4^{\circ} \mathrm{C}$ until use. Before examined under a confocal microscope, samples were posted on glass slides, excess FaGlu was draw off by bibulous paper strip, and glass slides were set in a dry, dark place at room temperature for $12 \mathrm{~h}$ (for drying). After drying, the samples were coated with paraffin oil, covered with a coverslip and sealed with nail polish. Samples were viewed by confocal laser scanning microscopy at $450 \mathrm{~nm}$ excitation. Images were analyzed with Fijy ImageJ software.

\section{Results and discussion}

In the development of $P$. lividus larvae, the first cells to appear are immunoreactive to 5-HT (5-HT-ir). The one 5-HT-ir flack-shape cell is detected in the gastrula stage at the apical pole of the larvae (Fig. 1A). Incubation in the 5-HT resulted in dramatic increase in the number of cells visualized with 5-HT antibody. 5-6 cells located at the apical pole and comprise the apical organ (AO). Solitary cells located medially to the compact $\mathrm{AO}$ and in the middle part of the larval body (Fig. 1B). When gastrula are incubated in 5-HTP, the 2-4 cells in the apical region express punctuate 5 -HT-positive signal. In addition, the fluorescent level increases in all larva cells, and the positive signal exceeding the background fluorescence occurs in the primary mesenchyme cells (Fig. 1C), which, according to the literature, participate in the formation of spicules (Okazaki, 1960; Galileo, Morrill, 1985). This result indicate that primary mesenchyme cells have inner decarboxylase activity and are capable to synthesize 5-HT after incubation with 5-HTP. The presence and activity of decarboxylase in primary mesenchyme cells need further investigations. No fluorescent signal was detected after FaGlu, neither in normal condition nor after DA and L-DOPA incubation.

At the early pluteus stage, a developed AO contains six 5-HT-ir cells (Fig. 1D). After incubation in 5-HT, additional 5-6 positive cells appear around $\mathrm{AO}$ and along the larval arms, (Fig. 1E). Thin basal cell processes became visible. Such configuration of the AO and peripheral 5-HT-ir cells was described for the much developed stage of 6-arm pluteus in the normal condition (Bisgrove, Burke, 1987). Incubation in 5-HTP leads to an increase in the background fluorescence level in all cells of the larva, appearance of slight fluorescence in mesenchymal cells and in punctate 5-HT-staining of the AO cells (Fig. 1F). The low level of 5-HT in AO cells after incubation in 5-HTP occurred in all our experiments. We suggested that the level of 5-HT was down regulated in response to high level of 5-HT produces by all cells of the larval body.

FaGlu did not visualize positive catecholamine signal at the early pluteus stage under normal condition (Fig. 1G). Incubation in DA resulted in appearance of two fluorescent cells located at the base of each larval arms. Thin processes are detected at the base of each cell. (Fig. 1H). These cells differ in location from 5HT-ir cells of the AO. In normal conditions, first DA cells were detected much later, at the 4-arm pluteus (Bisgrove, Burke, 1987). Incubation in L-DOPA resulted in background fluorescence increase in all larva cells. Some solitary brightly fluorescent cells occurred randomly scattered across the larval body (Fig. 1I).

Thus, serotonin transporter is active selectively in apical organ cells and in solitary nervous cells in the larval body and along the arm. Dopamine transporter is active in specific cells at the base of the arms. Incubation in respective 
Selective visualization of monoamine uptake and synthesis system in sea urchin larvae 165

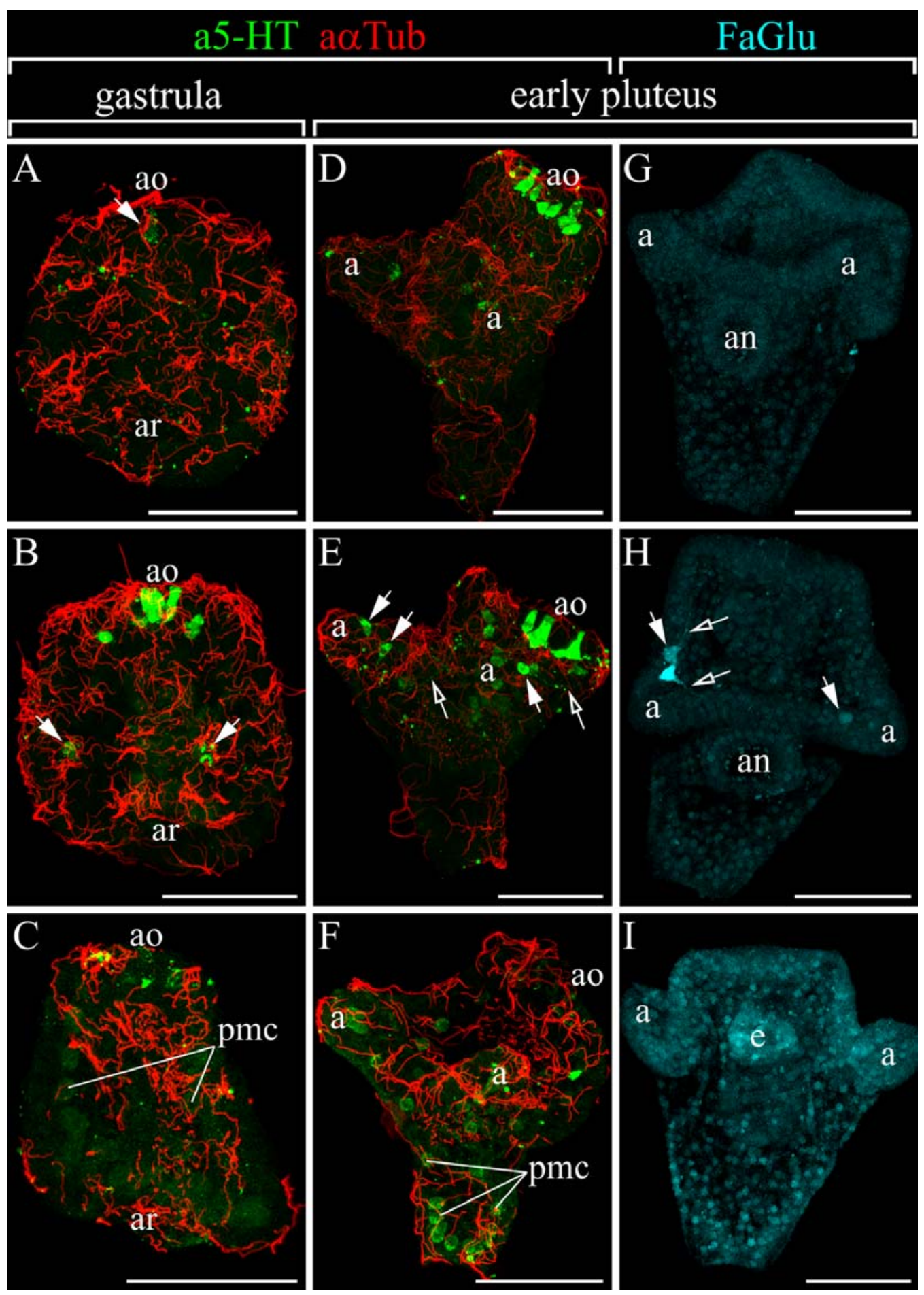


monoamine allows to visualize the detailed morphology of the cells including thin basal processes at much earlier stage than such cells appear under normal condition during development. To the contrary, decarboxylase (the final non-selective monoamine synthesis enzyme) is active in the most of the cells in larval body. Surprisingly, external 5-HTP and L-DOPA resulted in different pattern of cells producing 5HT and DA. While production of 5-HT is maximal in apical cells and in subpopulation of primary mesenchyme cells and slightly in most of the larval cells, DA production occurred in randomly scattered cells of the larval body which are not associated with any nervous structures. It is doubtful that two different decarboxylases exist in different cells in P.lividus larvae. More likely the different subpopulations of larval cells have specialized transporter for 5-HTP and L-DOPA. However such hypothesis needs additional experimental confirmation.

In molluscan larvae, incubation in 5-HTP resulted in selected visualization of nerve cells while incubation in 5-HT leads to non-specific increase of 5-HT level within all larval cells (Voronezhskaya et al., 2004; Voronezhskaya, unpublished data). These data indicate that in molluscs most of the cells have 5-HT transporter and only subpopulation of nerve cells express decarboxylase activity, while in sea urchin larvae the situation is vise versa. These comparative results represent species-specific features of serotonergic system in molluscs and sea ur- chins. To summarize, incubation in 5-HT and DA appear to be the selective method for better visualization of specific nerve cells (within AO and along the arms) and their detailed morphology during sea urchin larval development.

\section{Acknowledgements}

The authors thank the Optical Research Group of IDB RAS for technical assistance. The work was supported by the Russian Foundation for Basic Research (grants No. 16-34-01381 and No. 15-04-07573).

\section{References}

Bisgrove B., Burke R. 1987. Development of the nervous system of the pluteus larva of Strongylocentrotus droebachiensis // Cell and Tissue Research. Vol.248. No.2. P.335-343.

Galileo D.S., Morrill J.B. 1985. Patterns of Cells and Extracellular Material of the Sea Urchin Lytechinus variegatus (Echinodermata; Echinoidea) Embryo, From Hatched Blastula to Late Gastrula // Journal of Morphology. Vol.185. P.387-402.

Okazaki K. 1960. Skeleton formation of sea urchin larvae. II. Organic matrix of the spicule // Embryologia. Vol.5. Iss.3. P.283-320.

Sakharov D.A. 1991. Use of transmitter precursor in gastropod neuroethology // K.S. Kits, H.H. Boer, J. Joose (eds.). Molluscan neurobiology. Proc 3rd Symp. Mollusc Neurobiol. Amsterdam, North-Holland. P.236-242.

Voronezhskaya E.E., Khabarova M.Yu., Nezlin L.P. 2004. Apical sensory neurones mediate developmental retardation induced by conspecific environmental stimuli in freshwater pulmonate snails // Development. Vol.131. P.3671-3680.

Responsible editor E.N. Temereva

Fig. 1. Serotonergic and dopaminergic neuronal elements in the larvae of the sea urchin Paracentrotus lividus. Cilia identified by aTub antibodies. A-F - double immunostaining of 5-HT (green) and aTub (red); G-I - histochemical visualization of dopamine (cyan). A - normal gastrula; B - gastrula after incubation in 5-HT; $\mathrm{C}$ - gastrula after incubation in 5-HTP; D, G - normal early pluteus; $\mathrm{E}$ - early pluteus after incubation in 5-HT; F - early pluteus after incubation in 5-HTP; $\mathrm{H}$ - early pluteus after incubation in DA; I - early pluteus after incubation in L-DOPA.

Abbreviations: a — arm; an — anus; ao — apical organ; ar — archenteron; e — esophagus; pmc — primary mesenchyme cells. Arrows point 5 -HT-ir cell bodies, empty arrows point cell processes. Scale bars $50 \mu \mathrm{m}$.

Рис. 1. Серотонинергические и дофаминергические нейрональные элементы у личинок морского ежа Paracentrotus lividus. Реснички выявлены антителами к aTub. A-F - двойное иммунохимическое маркирование 5-HT (зеленый) и аTub (красный); G-I - гистохимическая визуализация дофамина (циан). А - гаструла; В - гаструла после инкубации в 5-НТ; С - гаструла после инкубации в 5-НТР; $\mathrm{D}, \mathrm{G}$ - ранний плутеус; $\mathrm{E}$ - ранний плутеус после инкубации в 5-HT; F - ранний плутеус после инкубации в 5-НTP; H - ранний плутеус после инкубации в DA; I - ранний плутеус после инкубации в L-DOPA.

Обозначения: a — руки; an — анус; ао — апикальный орган; ar — архентерон; е — глотка; ртс — первичные мезенхимальные клетки. Стрелками указаны тела клеток, иммунореактивных к 5-НТ; пустыми стрелками указаны длинные клеточные отростки. Масштаб $50 \mu \mathrm{m}$. 